\title{
Outcomes of pain management in chronic pancreatitis: experience from a tertiary care hospital in India
}

\author{
Kavin Sugumar $^{1}$ (D), Aparna Deshpande ${ }^{1}$ (D) \\ ${ }^{1}$ Seth GS and King Edward Memorial Hospital, Clinic of Surgery, Mumbai, India
}

\begin{abstract}
Objective: Chronic pancreatitis (CP) is a progressive inflammatory disorder that leads to irreversible destruction of exocrine and endocrine parenchyma. Little is known about outcomes of CP in the Indian subcontinent. We aim to study the treatment outcomes of CP in terms of pain severity in a tertiary hospital in India.

Material and Methods: This is a prospective cohort study of 75 patients diagnosed with CP. Data regarding patient demographics, symptoms, and imaging findings were recorded. Pain severity was recorded objectively by the visual analogue scale (VAS). Cambridge score was calculated, and patients were classified into mild, moderate and severe categories. Patients were treated appropriately, and pain scores were monitored at 3 months and 6 months after initial visit.

Results: Alcohol was the most common etiology (54\%) followed by idiopathic/unknown causes (34\%). Cambridge score or morphology on imaging did not affect pain severity $(p>0.05)$. History of smoking and larger duct diameter decreased the effectiveness of treatment in reducing pain while higher post prandial sugar levels increased effectiveness $(p<0.05)$. Pain relief did not differ between the treatment groups including analgesics, endoscopic or surgery ( $p>0.05)$.

Conclusion: CP presents earlier in the Indian population and represents a unique population with a greater proportion of idiopathic cases than western countries. Rather than pancreatic morphology or Cambridge score alone, a combination of morphology, pain severity and functional status can be utilized for formulating an individualized treatment plan. Present treatment strategies prove effective in treatment of CP.
\end{abstract}

Keywords: Chronic pancreatitis, pain, Cambridge score, treatment

Cite this article as: Sugumar K, Deshpande A. Outcomes of pain management in chronic pancreatitis: experience from a tertiary care hospital in India. Turk J Surg 2020; 36 (4): 359-367.

\section{Corresponding Author}

Kavin Sugumar

E-mail: dr.kavinsugumar@gmail.com

Received: 30.09 .2020

Accepted: 03.10 .2020

Available Online Date: 29.12 .2020

O Copyright 2020 by Turkish Surgical Society Available online at www.turkjsurg.com

DOI: $10.47717 /$ turkjsurg.2020.4924

\section{INTRODUCTION}

Chronic pancreatitis (CP) is a progressive inflammatory disorder of the pancreas that leads to irreversible destruction of both exocrine and endocrine parenchyma (1). It commonly affects middle aged individuals with a slightly higher incidence in males (2). There is an increasing trend in the incidence and prevalence of CP over the last decade worldwide (3-5). At present, the US healthcare system spends over 150 million dollars toward the management of CP (6). Nearly $2 / 3^{\text {rd }}$ of the patients have history of heavy alcohol consumption (150-175 g/d) for over a decade (7). Other common etiological factors include smoking, auto-immune, and idiopathic causes (2). Abdominal pain is the most common presenting symptom of CP which is caused due a multitude of reasons including recurrent or chronic inflammation of parenchyma, localized complications, or neurological mechanisms with nervous system changes (8). It is crucial to treat CP as soon as possible, because repeated episodes of inflammation can cause irreversible damage and make treatment less effective (9). Pain can severely reduce the quality of life and increase healthcare costs considerably in affected patients (8). Due to these reasons, it is considered as a significant health concern worldwide (10). There are many treatment strategies described in the literature for $C P$, and all involve a multidisciplinary team comprising surgical, gastroenterological, and radiologic team. Most therapeutic strategies are targeted towards alleviating pain. The initial mainstay of treatment includes symptomatic medication, most commonly NSAIDs (non-steroidal anti-inflammatory drugs) (8). Patients who do not respond to medication are subjected to either endoscopic or surgical treatment $(11,12)$. 
Compared to a prevalence of 10/100,000 in western countries, India, as well as other Asian countries, has an increased prevalence of CP (13). Recently, CP in India has shown a change, with an increased incidence in older patients, an increase in incidence of milder disease, increasing longevity, and increasing association with alcoholism and smoking (14). In addition to the etiologies described above, tropical pancreatitis is unique to Asian countries which comprises 3-5\% of the patients (15). These patients have a more aggressive course, affecting younger patients and commonly resulting in pancreatic cancer (16). At present, there is sparse literature concerned about the treatment outcomes of patients with CP in the Indian subcontinent. Herein, we aimed to describe the clinical course and treatment outcomes of patients diagnosed with CP at a tertiary hospital in India. We primarily focused on pain severity as the main outcome before and after treatment. We also studied the factors affecting pain severity before and after treatment.

\section{MATERIAL and METHODS}

This is a prospective cohort study conducted at the Department of General Surgery, King Edward Memorial Hospital, Mumbai, India a tertiary care hospital. Patients diagnosed with chronic pancreatitis were enrolled between June 2016 and January 2017. A written informed consent was obtained from all eligible patients. The study was approved by the institutional ethics committee (IEC number: EC/76/2016) and all procedures followed were in accordance with the ethical standards of the responsible committee on human experimentation (institutional) and with the Helsinki Declaration of 1975, as revised in 2000. This study was structured utilizing the STROBE (strengthening of observational studies in epidemiology) guidelines (17).

The study included patients with CP diagnosed by contrast-enhanced computer tomography (CECT abdomen) and/ or magnetic resonance cholangiopancreatography (MRCP) and relevant clinical symptoms including severe abdominal pain, malabsorption, and/or features of diabetes mellitus. Patients who had underlying pancreatic malignancy were excluded. Details in regard to history were recorded including age, sex, presenting symptoms, duration of symptoms, number of prior admissions for similar symptoms, history of alcohol intake and smoking, gall bladder disease, and history of diabetes mellitus. Pain severity was objectively measured using the visual analog scale (VAS) and graded from 0-10 (18). Anorexia or malnutrition was defined as a body mass index (BMI) of < 18. CECT-abdomen was used to record the following findings including pancreatic atrophy, calcification, features of acute pancreatitis, portal vein thrombosis, and ascites. Basic laboratory investigations carried out included fasting blood sugar, post-prandial blood sugar, serum lipase, aspartate transaminase (AST), alanine transaminase (ALT), and fecal fat test.
Patients were treated with either symptomatic management only, or endoscopic and/or surgery and symptomatic treatment post intervention, depending on the treating surgeon's assessment of symptoms and morphological findings on CECT, MRI, or EUS (endoscopic ultrasound). Symptomatic treatment included NSAIDs with or without opioid analgesics for pain, pancreatic enzyme supplementation and diet modification as the standard of care. Patients were instructed to attend follow-up visits at monthly intervals, irrespective of their symptoms. Patients who did not respond symptomatically to conservative therapy was offered either endoscopic or surgical treatment depending on disease morphology. Response to therapy was measured by pain severity (VAS score) which was measured at 3 and 6 months after initial visit.

\section{Statistical Analysis}

Continuous data including age, duration of symptoms, number of admissions, fasting and post-prandial blood sugar, serum lipase, ALT and AST, pancreatic duct diameter, and pain score was described as means with range. Categorical variables including gender, presenting complaints, history of alcohol intake, smoking, gall stone disease, Cambridge score, CECT findings, and treatment provided was described as frequency with percentages.

Initial univariate linear regression was used to study the clinical factors associated with pain severity (VAS) at first visit. Predictor variables were selected based on their unadjusted log-rank statistical significance ( $p<=0.250$ ) on the univariate analyses for all the potential confounders (e.g. age, duration of symptoms, number of prior admission, etc.) separately, for the initial multivariate model. A backward step-wise elimination procedure, based on the Akaike Information Criteria and statistical significance ( $p<=0.05$ ), was then used to achieve the final multivariate model presented.

Wilcoxon rank-sum test was used to study the change in pain severity from first visit to 3 - and 6-months post initial visit. Mixed effects multiple linear regression model fit by REML (Restricted maximum likelihood) was used to account for the correlation due to multiple visits by same patient: pre-treatment, 3-months and 6-months clinic visit. Univariate and multivariate analyses were performed as described previously. All statistical analysis was performed using StataSE software (StataCorp. 2019. Stata Statistical Software: Release 16. College Station, TX: StataCorp LLC) and statistical significance was defined as $p<0.05$.

\section{RESULTS}

A total of 100 patients were enrolled in the study. Out of the 100 patients, 25 were excluded with the following reasons: 8 patients did not receive treatment at our hospital and 17 patients were lost to follow-up. Seventy-five patients underwent treatment and were followed until 6 months and were included into the study. The study flow diagram is shown in Figure 1. 


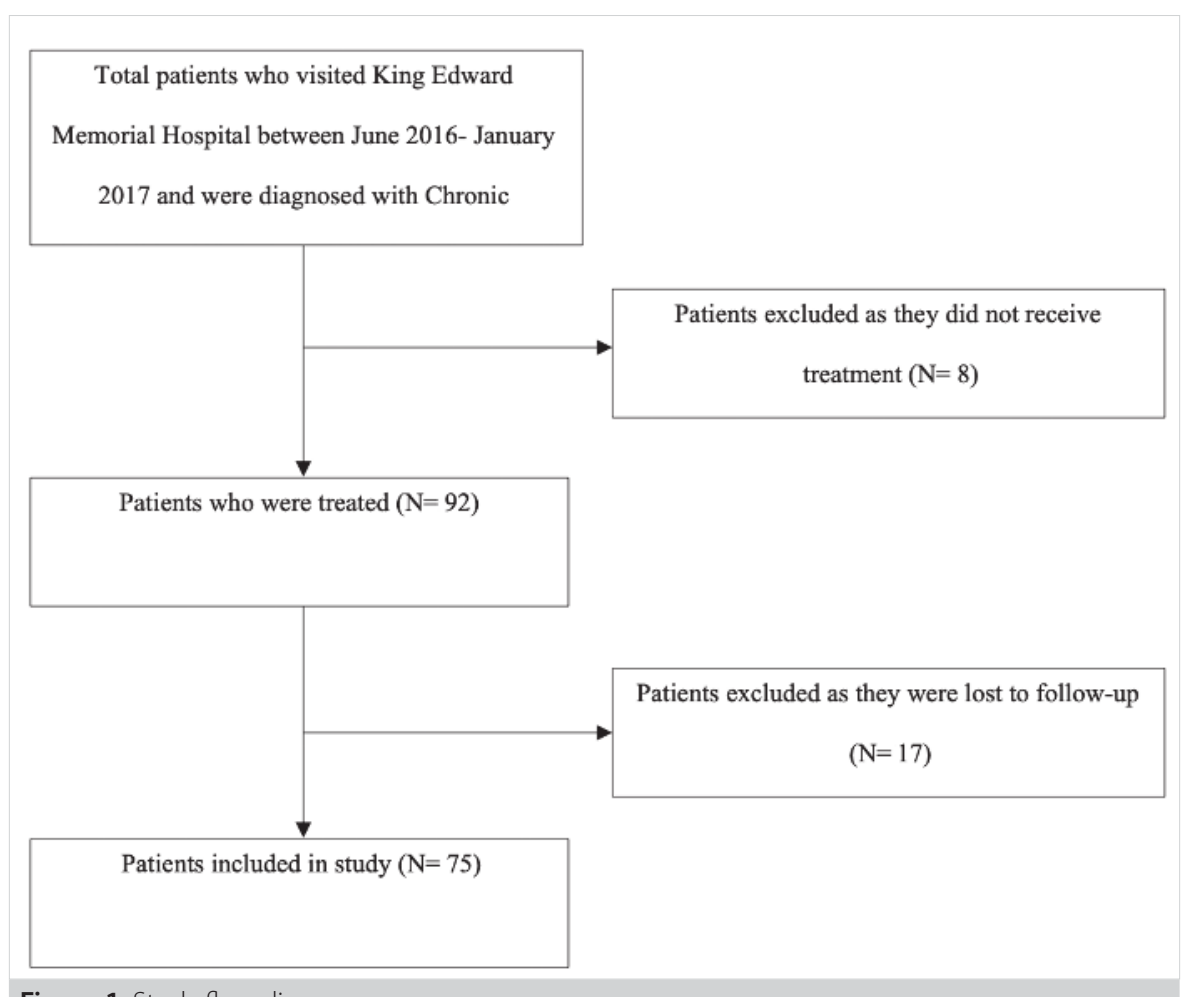

Figure 1. Study flow diagram

Baseline demographics of the 75 patients are shown in Table 1. Thirty-four patients (45\%) were alcoholic and 13 patients (17\%) were smokers. Four patients (5\%) had prior history of gall stone disease. Patients had a mean symptom duration of 2.5 years (range: 3 months - 15 years). Mean number of admissions prior to initial visit was 3 (range 1-3).

Eight patients (11\%) underwent endoscopic intervention including pancreatic duct stenting and/or ESWL (extracorporeal shortwave lithotripsy). Sixteen patients (21\%) underwent surgery including lateral pancreaticoduodenectomy (14/75, 19\%) and distal pancreatectomy $(2 / 75,3 \%)$. Indication for surgery was intractable pain $(16 / 16,100 \%)$. Of this, 14 patients had a dilated pancreatic duct size greater than $6 \mathrm{~mm}$, and two patients had a pseudocyst. (Table 1). Out of the patients who underwent surgery, 1 (6\%) patient developed post-operative pancreatic fistula. The surgical drain was kept in-situ for a month post-surgery until the drain output reduced, and then it was removed. One patient developed superficial wound infection (6\%), which healed with adequate wound dressing. Median length of stay for all patients was 7 days. All patients were discharged home with adequate chest physiotherapy exercises. None of the patients required any re-operation. There was no 30- and 90- day readmission or mortality.

At first visit, malabsorption was associated with a greater pain severity (Regression coefficient: $2.3, p=0.015$ ). Prior history of diabetes mellitus (Regression coefficient: $-1.3, p=0.03$ ) and higher post-prandial blood sugar (Regression coefficient: $-0.008, p=$
0.03) was associated with less pain. (Table 2). On multivariate analysis, malabsorption (Regression coefficient: $4.5, p=0.008$ ) continued to be associated with greater pain and history of diabetes mellitus (Regression coefficient: $-2.3, p=0.01$ ), and high postprandial blood sugar (Regression coefficient: $-0.1, p=0.04$ ) was associated with less pain (Table 2).

Mean pain score at initial visit was 6.24 (range: $0-10$ ) and at 3 months follow-up, it was 0.94 (range: 0-6) and at 6 months follow up, it was 0.78 (range: 0-6). There was a significant change in pain severity at 3- and 6- month follow-up compared to pre-treatment pain scores $(p<0.0001, p<0.0001)$. Pain severity remained similar at 3- and 6-months $(p=0.863$ ) (Table 3). The change in pain severity along with 95\% confidence interval is shown in Figure 2.

Patients were likely to have decreased response to treatment if they had a history of smoking (Regression coefficient: 1.03, $p=$ 0.01), greater pancreatic duct diameter (Regression coefficient: -0.09, $p=0.01$ ) or postal vein thrombosis (Regression coefficient: -0.81, $p=0.04$ ) on univariate analysis (Table 4). On multivariate analysis, history of smoking (Regression coefficient: 1.04, $\mathrm{p}=0.004$ ) and duct diameter (Regression coefficient: $0.087, \mathrm{p}=$ 0.01 ) continued to decrease response to treatment. Portal vein thrombosis did not show a significant relationship on multivariate analysis. Higher post prandial blood sugar increased pain response to treatment (Regression coefficient: $-0.005, p=0.049$ ) on multivariate analysis. 
Table 1. Patient characteristics

\begin{tabular}{|c|c|}
\hline Parameter & Mean with range or $\mathrm{n}(\%)$ \\
\hline Sample size (n) & 75 \\
\hline Age (years) & $35(17-67)$ \\
\hline $\begin{array}{l}\text { Gender } \\
\text { Male } \\
\text { Female }\end{array}$ & $\begin{array}{l}56(75 \%) \\
19(25 \%)\end{array}$ \\
\hline $\begin{array}{l}\text { Presenting symptoms } \\
\text { Abdominal pain } \\
\text { Vomiting } \\
\text { Anorexia/ malnutrition }(\mathrm{BMl}<18) \\
\text { Malabsorption }\end{array}$ & $\begin{array}{l}75(100 \%) \\
60(80 \%) \\
37(49 \%) \\
70(93 \%)\end{array}$ \\
\hline Duration of symptoms & 2.5 years ( 3 months- 15 years) \\
\hline Number of prior admissions & $3(1-12)$ \\
\hline H/o alcohol consumption & $39(52 \%)$ \\
\hline H/o smoking & $13(17 \%)$ \\
\hline H/o Gall stone disease & $4(5 \%)$ \\
\hline H/o Diabetes Mellitus & $12(16 \%)$ \\
\hline $\begin{array}{l}\text { Lab parameters } \\
\text { Fasting blood sugar }(\mathrm{mg} / \mathrm{dl}) \\
\text { Post-prandial blood sugar }(\mathrm{mg} / \mathrm{dl}) \\
\text { Serum lipase }(\mathrm{U} / \mathrm{L}) \\
\text { Fecal fat test } \\
\text { AST }(\mathrm{U} / \mathrm{L}) \\
\text { ALT }(\mathrm{U} / \mathrm{L})\end{array}$ & $\begin{array}{l}82(44-188) \\
136(88-305) \\
375(12-4300) \\
19(25 \%) \\
36(13-124) \\
33(10-124)\end{array}$ \\
\hline $\begin{array}{l}\text { Cambridge score } \\
\text { Mild } \\
\text { Moderate } \\
\text { Severe }\end{array}$ & $\begin{array}{l}10(13 \%) \\
15(20 \%) \\
50(67 \%)\end{array}$ \\
\hline $\begin{array}{l}\text { CECT findings } \\
\text { Atrophy } \\
\text { Calcification } \\
\text { Portal venous thrombosis } \\
\text { Ascites } \\
\text { Acute pancreatitis }\end{array}$ & $\begin{array}{l}49(65 \%) \\
59(79 \%) \\
16(21 \%) \\
3(4 \%) \\
12(16 \%)\end{array}$ \\
\hline $\begin{array}{l}\text { Pancreatic duct diameter } \\
\quad<6 \mathrm{~mm} \\
\quad>6 \mathrm{~mm}\end{array}$ & $\begin{array}{l}42(56 \%) \\
33(44 \%)\end{array}$ \\
\hline $\begin{array}{l}\text { Conservative treatment } \\
\text { NSAIDs } \\
\text { Opioid analgesics } \\
\text { Enzyme supplementation } \\
10.000 \mathrm{U} \\
25000 \mathrm{U} \\
40.000 \mathrm{U}\end{array}$ & $\begin{array}{l}74(99 \%) \\
29(39 \%) \\
75(100 \%) \\
44(59 \%) \\
29(39 \%) \\
1(1 \%) \\
\end{array}$ \\
\hline Endoscopic intervention & $8(11 \%)$ \\
\hline $\begin{array}{l}\text { Surgery } \\
\text { Lateral pancreaticojejunostomy } \\
\text { Distal pancreatectomy }\end{array}$ & $\begin{array}{l}16(21 \%) \\
14(19 \%) \\
2(3 \%)\end{array}$ \\
\hline
\end{tabular}

Pain reduction did not depend on whether patients received medical, endoscopic (Regression coefficient: $-0.42, p=0.34$ ), or surgery (Regression coefficient: $0.37, p=0.16$ ) treatment. How- ever, among those that received only conservative therapy, patients who received opioids in addition to NSAIDs had better pain relief (Regression coefficient: $-0.44, p=0.001$ ). However, on multivariate analysis, opioid addition to NSADIS lost statistical significance (Regression coefficient: 0.38, $p=0.26$ ).

\section{DISCUSSION}

Our study adds to the current literature on the outcomes of patients with CP in the Indian subcontinent. Mean age of presentation was 35 years, which is much earlier compared to the worldwide median age of 51-58 years $(19,20)$. According to two other studies conducted in India, the age of the patients with CP was between 15 and 38 years, and 33 years respectively $(21,22)$. The earlier course of this disease could be due to the higher proportion of idiopathic or tropical variant of CP that is common in the Indian subcontinent, which presents with large pancreatic calculi that affect young malnourished individuals and have a more aggressive course $(13,16,21)$. In our study, though $45 \%$, $14 \%$, and $5 \%$ of patients had alcoholic, smoking or gall-bladder disease as potential etiologies, the remaining 34\% did not have any discernable etiology and could be considered idiopathic. According to Yadav et al, alcohol is the most common risk factor, but recently alcohol use and smoking levels have been relatively stable or have declined (23). Several other studies have similarly shown an increased prevalence of idiopathic CP in the Indian population $(15,21,22)$. This study showed a greater male-to-female ratio of 3:1 which is similar to previous studies (24).

Abdominal pain was the most common presenting symptom of CP. Malnutrition was present in 49\% of the patients. In a similar study conducted in Ireland, 78\% of the patients had pain, $15 \%$ had vomiting, and 35\% had malnutrition (25). Patients were symptomatic for around 2-3 years before they visited our hospital, which is also similar to other studies (26). Most of them were not appropriately managed prior to initial visit even though they had prior in-patient admissions for similar symptoms. This signifies misdiagnosis or delayed diagnosis of CP. Nearly $2 / 3^{\text {rd }}$ of CP patients had a severe Cambridge score. This could imply that mild/early CP is under-diagnosed among patients of CP. A panel of pancreatic function tests along with clinical features and morphological changes among patients suspected of CP may be required for the diagnosis of early CP (27).

Pancreatic calcification was present in $79 \%$ of the patients which is higher than the expected $30-50 \%$ (28). In previous studies conducted in India, there was 95-97\% calcification and there was no difference between different etiologies (22). Pancreatic atrophy was present in $65 \%$ of the patients, which signifies the severity and chronicity of the disease. Large duct disease was present in $44 \%$ of patients, which signifies advanced disease (26).

Even though pain is said to have quicker onset in younger patients (<35 years) (29), our study showed that pain severity did 
Table 2. Factors affecting VAS pain score at diagnosis

\begin{tabular}{|c|c|c|c|c|}
\hline Parameter & Univariate regression coefficient & $\mathrm{p}$ & Multivariate regression coefficient & $\mathrm{p}$ \\
\hline Age & -0.02 & 0.31 & & \\
\hline Gender & -0.67 & 0.22 & & \\
\hline $\begin{array}{l}\text { Presenting symptoms } \\
\text { Vomiting } \\
\text { Anorexia or malnutrition }(\mathrm{BMl}<18) \\
\text { Malabsorption }\end{array}$ & $\begin{array}{c}-0.63 \\
0.32 \\
2.3\end{array}$ & $\begin{array}{c}0.29 \\
0.50 \\
\mathbf{0 . 0 1 5}\end{array}$ & 4.5 & 0.008 \\
\hline Duration of symptoms & 1 & 0.99 & & \\
\hline Number of prior admissions & 0.13 & 0.18 & & \\
\hline H/o alcohol consumption & -0.07 & 0.88 & & \\
\hline H/o smoking & 0.82 & 0.19 & & \\
\hline H/o Gall stone disease & -1.3 & 0.22 & & \\
\hline H/o Diabetes Mellitus & -1.3 & 0.03 & -2.3 & 0.01 \\
\hline $\begin{array}{l}\text { Lab parameters } \\
\text { Fasting blood sugar (mg/dl) } \\
\text { Post-prandial blood sugar (mg/dl) } \\
\text { Serum lipase }(\mathrm{U} / \mathrm{L}) \\
\text { Fecal fat test } \\
\text { AST }(\mathrm{U} / \mathrm{L}) \\
\text { ALT }(\mathrm{U} / \mathrm{L})\end{array}$ & $\begin{array}{l}-0.01 \\
-0.008 \\
-0.0001 \\
-0.22 \\
0.009 \\
-0.01\end{array}$ & $\begin{array}{l}0.07 \\
\mathbf{0 . 0 3} \\
0.71 \\
0.67 \\
0.38 \\
0.35\end{array}$ & -0.1 & 0.04 \\
\hline Cambridge score & 0.09 & 0.65 & & \\
\hline $\begin{array}{l}\text { CECT findings } \\
\text { Atrophy } \\
\text { Calcification } \\
\text { Portal venous thrombosis } \\
\text { Ascites } \\
\text { Acute pancreatitis }\end{array}$ & $\begin{array}{c}-0.69 \\
-0.04 \\
1.04 \\
0.79 \\
-1.07\end{array}$ & $\begin{array}{l}0.173 \\
0.94 \\
0.07 \\
0.52 \\
0.101\end{array}$ & & \\
\hline Pancreatic duct diameter & 0.08 & 0.13 & & \\
\hline
\end{tabular}

Table 3. Pain score change at first visit, 3 and 6 months

\section{Parameter}

Pain score at first visit $\left(\mathrm{P}_{\mathrm{TO}}\right)$

Pain score at 3 months $\left(\mathrm{P}_{\mathrm{T} 3}\right)$

Pain score at 6 months $\left(\mathrm{P}_{\mathrm{T}}\right)$

Pain score at 3 months compared to diagnosis $\left(\mathrm{P}_{\mathrm{T} 3}-\mathrm{P}_{\mathrm{TO}}\right)$

Pain score at 6 months compared to diagnosis $\left(\mathrm{P}_{T 6}-\mathrm{P}_{T 0}\right)$

Pain score at 6 months compared to 3 months $\left(\mathrm{P}_{T 6}-\mathrm{P}_{T 3}\right)$

not vary based on age. Patients having malabsorption had more pain severity at diagnosis. This could be explained by the severity of pancreatic exocrine insufficiency causing fat indigestion and pain due to repeated inflammation of the parenchyma and surrounding nerve tissue (8). Presence of diabetes mellitus resulted in decreased pain severity at diagnosis. Diabetes causes neuropathy and could explain the alteration in pain severity in the sample. Cambridge score or morphology including atrophy, calcification, duct diameter on imaging was not associated with pain severity of CP. Similarly, Frøkjær and Wilcox et al. were not able to demonstrate a significant relationship between pain and morphological changes like fibrosis and atrophy in pancreatic parenchyma $(30,31)$. Studies have compared duct diameter with pain severity with similar results (32).

There was significant improvement in pain severity at 3- and 6-months after initiating treatment. There was no relapse in 


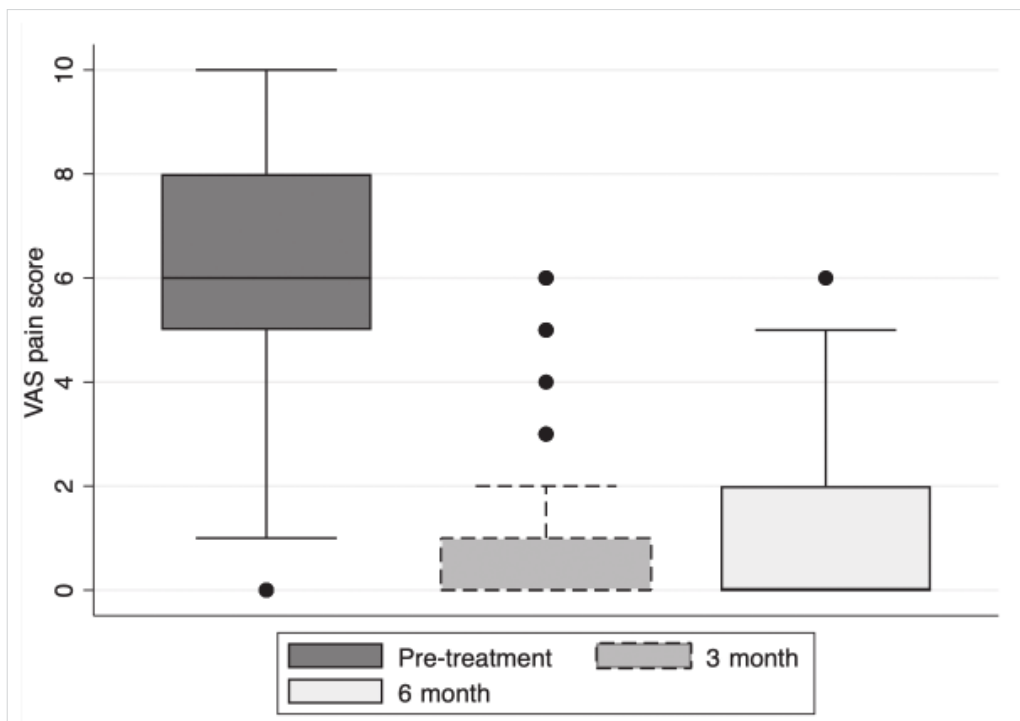

Figure 2. Distribution of pain severity among CP patients at the initial visit, 3 and 6 months follow-up.

Table 4. Factors affecting change in pain severity up to 6 months

\begin{tabular}{|c|c|c|c|c|}
\hline Parameter & Univariate Regression Coefficient & $\mathrm{p}$ & Multivariate Regression Coefficient & $\mathrm{p}$ \\
\hline Age & -0.0005 & 0.96 & & \\
\hline Gender & -0.45 & 0.24 & & \\
\hline $\begin{array}{l}\text { Symptoms } \\
\text { Vomiting } \\
\text { Anorexia or malnutrition } \\
\text { Malabsorption }\end{array}$ & $\begin{array}{c}-0.48 \\
0.61 \\
1.2\end{array}$ & $\begin{array}{l}0.25 \\
0.06 \\
0.05\end{array}$ & & \\
\hline H/o prior admission & 0.05 & 0.46 & & \\
\hline H/o alcohol intake & 0.06 & 0.86 & & \\
\hline H/o smoking & 1.03 & 0.01 & 1.04 & 0.004 \\
\hline H/o gall stone disease & -1.01 & 0.20 & & \\
\hline H/o Diabetes Mellitus & -0.85 & 0.98 & & \\
\hline Period of symptoms & 0.001 & & & \\
\hline $\begin{array}{l}\text { Lab values } \\
\text { Serum lipase } \\
\text { Fecal fat test } \\
\text { AST } \\
\text { ALT } \\
\text { Fasting blood sugar } \\
\text { Post prandial blood sugar }\end{array}$ & $\begin{array}{c}0.0001 \\
-2.79 \\
0.009 \\
-0.008 \\
-0.008 \\
-0.005\end{array}$ & $\begin{array}{l}0.66 \\
0.45 \\
0.20 \\
0.41 \\
0.13 \\
0.05\end{array}$ & $\begin{array}{l}1.164 \\
-0.005\end{array}$ & $\begin{array}{l}0.027 \\
0.049\end{array}$ \\
\hline $\begin{array}{l}\text { CECT findings } \\
\text { Atrophy } \\
\text { Pancreatic calcification } \\
\text { Pancreatic duct diameter } \\
\text { Acute pancreatitis } \\
\text { Portal venous thrombosis } \\
\text { Ascites }\end{array}$ & $\begin{array}{c}-0.09 \\
-0.03 \\
0.09 \\
-0.36 \\
0.81 \\
0.11\end{array}$ & $\begin{array}{l}0.80 \\
0.93 \\
\mathbf{0 . 0 1} \\
0.44 \\
\mathbf{0 . 0 4} \\
0.90\end{array}$ & 0.087 & 0.01 \\
\hline Cambridge score & 0.05 & 0.73 & & \\
\hline $\begin{array}{l}\text { Treatment type } \\
\text { Analgesics } \\
\text { Endoscopic intervention } \\
\text { Surgery }\end{array}$ & $\begin{array}{c}\text { Reference } \\
-0.42 \\
0.37\end{array}$ & $\begin{array}{l}0.34 \\
0.16 \\
\end{array}$ & $\begin{array}{c}-0.25 \\
0.27\end{array}$ & $\begin{array}{l}0.69 \\
0.39 \\
\end{array}$ \\
\hline $\begin{array}{l}\text { Medical management } \\
\text { NSAID } \\
\text { NSAID \& opioids }\end{array}$ & $\begin{array}{c}\text { Reference } \\
-0.44\end{array}$ & 0.001 & 0.38 & 0.26 \\
\hline
\end{tabular}


symptoms at 6 months compared to 3 months. History of smoking was likely to decrease response to therapy for patients undergoing treatment. Smoking is considered to aggravate chronic pain according to previous studies, which could explain the heightened pain compared to others (33). Increased pancreatic duct diameter morphology caused more pain post-treatment compared to others. Large duct disease signifies advanced disease and could be the reason for this finding (16). Higher post prandial blood sugar increased response to treatment. This could be explained by the underlying neuropathy that affects pain experienced by the patients.

Our results showed that pain response was comparable among different treatment groups; either medical, endoscopic or surgery. For those patients only receiving analgesics, addition of opioids to NSAIDs increased pain relief. This is in accordance with the WHO principles of the "pain relief ladder". This is based on the principle of the serial addition of drugs of increasing analgesic potency, until pain relief is established (34). However, on performing multivariate analysis, opioid addition did not increase pain relief.

In our study, all patients initially received analgesics, and those that did not respond to medication at first follow-up visit (1-month) were selected for intervention. Endoscopic and various surgical drainage procedures are available for patients with intractable pain who do not respond to conservative management. The cause of pain is still an area of controversy but various mechanisms have been described, such as large duct disease due to proximal structuring of duct or main duct stones causing pancreatic ductal hypertension, defective blood supply to the pancreas due to fibrosis, or chronic inflammation of adjacent nerve plexus (35). In our study, 95\% of the patients who needed surgery had evidence of large duct disease. This is indicative of intraductal hypertension causing atrophy and ischemia of the gland, which can aggravate pain. Drainage procedure like lateral pancreatojejunostomy, or decompression like distal pancreatectomy helps relieve this pressure within the ductal system and cause pain relief. The similar could be said for endoscopic stenting or lithotripsy which attempt to relieve ductal obstruction (35). Various studies have shown that surgery is associated with better pain relief compared to endoscopic procedures. In addition, patients usually undergo multiple endoscopic procedures compared to surgery (36). We believe that the similar pain response to the three treatment modalities in our study may be due to the fact that treatments were overlapping among few patients. However, at the same time our results show that a uniform strategy of management can result in consistent pain relief among all patients.

Some of the limitations of the study include a small sample size and lack of long-term follow up beyond 6 months. Further follow-up of patients could help study relapse and long-term out- comes of treatment strategies. Our only outcome was pain, and we did not look at other outcomes like malnutrition, quality of life or functional status. The study was only observational and not controlled which could decrease the validity of results. Larger clinical trials may be performed in the Indian population to compare treatment strategies and long-term outcomes of such patients.

To conclude, CP presents earlier in the Indian population and is commonly under-diagnosed. This represents a unique population with a greater proportion of idiopathic cases than western countries. Abdominal pain and malnutrition are the most debilitating features of CP and must be primarily focused in such patients. Rather than pancreatic morphology on imaging or Cambridge score alone, a combination of morphology, pain severity and functional status of the pancreas may be utilized for formulating an individualized treatment plan. The current treatment strategies employed are effective in controlling pain in patients with $C P$.

Ethics Committee Approval: The approval for this study was obtained from Seth GS Medical College and KEM Hospital Ethics Committee (Decision No: 562/16, Date: 20.06.2016).

Peer-review: Externally peer-reviewed.

Author Contributions: Concept - K.S., A.D.; Design - K.S., A.D.; Supervision - A.D.; Data Collection and/or Processing - K.S.; Analysis and/or Interpretation - K.S.; Literature Review - K.S., A.D.; Writing Manuscript - K.S., A.D.; Critical Reviews - A.D.

Conflict of Interest: All authors declare that they have no competing interests.

Financial Disclosure: No financial support was used for this study.

\section{REFERENCES}

1. Kleeff J, Whitcomb DC, Shimosegawa T, Esposito I, Lerch MM, Gress T, et al. Chronic pancreatitis. Nat Rev Dis Primers 2017; 3: 17060. Epub 2017 Sep 7. [CrossRef]

2. Raimondi S, Lowenfels AB, Morselli-Labate AM, Maisonneuve P, Pezzilli R. Pancreatic cancer in chronic pancreatitis; Aetiology, incidence, and early detection. Best Pract Res Clin Gastroenterol 2010; 24(3): 349-58. [CrossRef]

3. Wang LW, Li ZS, Li SD, Jin ZD, Zou DW, Chen F. Prevalence and clinical features of chronic pancreatitis in China: A retrospective multicenter analysis over 10 years. Pancreas 2009; 38(3): 248-54. [CrossRef]

4. Balaji LN, Tandon RK, Tandon BN, Banks PA. Prevalence and clinical features of chronic pancreatitis in southern India. Int J Pancreatol 1994; 15(1): 29-34. [CrossRef]

5. Yadav D, Timmons L, Benson JT, Dierkhising RA, Chari ST. Incidence, prevalence, and survival of chronic pancreatitis: A population-based study. Am J Gastroenterol 2011; 106(12): 2192-9. [CrossRef]

6. Peery AF, Crockett SD, Barritt AS, Dellon ES, Eluri S, Gangarosa LM, et al. Burden of gastrointestinal, liver, and pancreatic diseases in the United States. Gastroenterology 2019; 156(1): 254-72. [CrossRef] 
7. Sarles H, Bernard JP, Gullo L. Pathogenesis of chronic pancreatitis. Gut 1990; 31(6): 629-32. [CrossRef]

8. Drewes AM, Bouwense SAW, Campbell CM, Ceyhan GO, Delhaye M, Demir IE, et al. Guidelines for the understanding and management of pain in chronic pancreatitis. Pancreatology 2017; 17(5): 720-31. [CrossRef]

9. Bordaçahar B, Couvelard A, Vullierme MP, Bucchini L, Sauvanet A, Dokmak S, et al. Predicting the efficacy of surgery for pain relief in patients with alcoholic chronic pancreatitis. Surg (United States) 2013, 19(42): 7292-301. [CrossRef]

10. Wassef W, Dewitt J, McGreevy K, Wilcox M, Whitcomb D, Yadav D, et al. Pancreatitis quality of life instrument: A psychometric evaluation. Am J Gastroenterol 2016; 111(8): 1177-86. [CrossRef]

11. Cahen DL, Gouma DJ, Nio Y, Rauws EAJ, Boermeester MA, Busch OR, et al. Endoscopic versus surgical drainage of the pancreatic duct in chronic pancreatitis. N Engl J Med 2007; 356(7): 676-84. [CrossRef]

12. Chinnakotla S, Bellin M, Beilman G, Dunn T, Freeman M, Schwarzenberg S, et al. Total pancreatectomy (TP) and islet auto transplantation (IAT) in children with painful chronic pancreatitis (CP). Am J Transplant 2014; 260(1): 56-64. [CrossRef]

13. Garg PK. Chronic pancreatitis in India and Asia. Curr Gastroenterol Rep 2012; 14(2): 118-24. [CrossRef]

14. Udayakumar N, Jayanthi V. Chronic pancreatitis in India: The changing spectrum. Postgrad Med J 2007; 83(983): 562-3. [CrossRef]

15. Garg PK, Tandon RK. Survey on chronic pancreatitis in the Asia-Pacific region. J Gastroenterol Hepatol 2004; 19(9): 998-1004. [CrossRef]

16. Tandon RK, Garg PK. Tropical pancreatitis. Dig Dis 2004; 19(9): 9981004. [CrossRef]

17. Vandenbroucke JP, Von Elm E, Altman DG, Gøtzsche PC, Mulrow CD, Pocock SJ, et al. Strengthening the reporting of observational studies in epidemiology (STROBE): Explanation and elaboration. PLOS Med 2014; 12(12): 1500-24. [CrossRef]

18. Boonstra AM, Schiphorst Preuper HR, Reneman MF, Posthumus JB, Stewart RE. Reliability and validity of the visual analogue scale for disability in patients with chronic musculoskeletal pain. Int J Rehabil Res 2008; 31(2): 165-9. [CrossRef]

19. Wilcox CM, Sandhu BS, Singh V, Gelrud A, Abberbock JN, Sherman S, et al. Racial Differences in the Clinical Profile, Causes, and Outcome of Chronic Pancreatitis. Am J Gastroenterol 2016; 111(10): 1488-96. [CrossRef]

20. Hirota M, Shimosegawa T, Masamune A, Kikuta K, Kume K, Hamada $S$, et al. The seventh nationwide epidemiological survey for chronic pancreatitis in Japan: Clinical significance of smoking habit in Japanese patients. Pancreatology 2014; 14(6): 490-6. [CrossRef]

21. Midha S, Khajuria R, Shastri S, Kabra M, Garg PK. Idiopathic chronic pancreatitis in India: Phenotypic characterisation and strong genetic susceptibility due to SPINK1 and CFTR gene mutations. Gut 2010; 59(6): 800-7. [CrossRef]
22. Bhasin DK, Singh G, Rana SS, Chowdry SM, Shafia N, Malhotra S, et al. Clinical profile of idiopathic chronic pancreatitis in North India. Clin Gastroenterol Hepatol 2009; 7(5): 594-9. [CrossRef]

23. Yadav $D$, Lowenfels $A B$. The epidemiology of pancreatitis and pancreatic cancer. Gastroenterology 2013; 144(6): 1252-61. [CrossRef]

24. Lévy P, Barthet M, Mollard BR, Amouretti M, Marion-Audibert AM, Dyard F. Estimation of the prevalence and incidence of chronic pancreatitis and its complications. Gastroentérologie Clin Biol 2006; 30(67): 838-44. [CrossRef]

25. Maev IV. Epidemiological and molecular-genetic aspects of the association between chronic pancreatitis and pancreatic cancer. Eksp Klin Gastroenterol 2005; (2): 12-6,106. [CrossRef]

26. Sinha SK, Kochhar R. Is the profile of chronic pancreatitis in India changing? Indian J Gastroenterol 2014; 33(3): 216-8. [CrossRef]

27. Cavallini G, Frulloni L, Pederzoli P, Talamini G, Bovo P, Bassi C, et al. Long-term follow-up of patients with chronic pancreatitis in Italy. Scand J Gastroenterol 1998; 33(8): 880-9. [CrossRef]

28. Bell $L G$, Hines LJ, Doane WA. Pancreatic calcification. US Armed Forces Med J 1956; 7: 348-62. [CrossRef]

29. Rajesh G, Veena AB, Menon S, Balakrishnan V. Clinical profile of earlyonset and late-onset idiopathic chronic pancreatitis in South India. Indian J Gastroenterol 2014; 33(3): 231-6. [CrossRef]

30. Wilcox CM, Yadav D, Ye T, Gardner TB, Gelrud A, Sandhu BS, et al. Chronic pancreatitis pain pattern and severity are independent of abdominal imaging findings. Clin Gastroenterol Hepatol 2015; 13(3): 552-60. [CrossRef]

31. Frøkjær JB, Olesen SS, Drewes AM. Fibrosis, atrophy, and ductal pathology in chronic pancreatitis are associated with pancreatic function but independent of symptoms. Pancreas 2013; 42(7): 1182-7. [CrossRef]

32. Karanjia ND, Singh SM, Widdison AL, Lutrin FJ, Reber HA. Pancreatic ductal and interstitial pressures in cats with chronic pancreatitis. Dig Dis Sci 1992; 37(2): 268-73. [CrossRef]

33. Ditre JW, Brandon TH, Zale EL, Meagher MM. Pain, nicotine, and smoking: Research findings and mechanistic considerations. Psychol Bull 2011; 137(6): 1065-93. [CrossRef]

34. Jadad AR, Browman GP. The WHO analgesic ladder for cancer pain management: Stepping up the quality of its evaluation. JAMA 1995; 274(23) :1870-3. [CrossRef]

35. Morrison CP, Wemyss-Holden SA, Partensky C, Maddern GJ. Surgical management of intractable pain in chronic pancreatitis: Past and present. J Hepatobiliary Pancreat Surg 2002; 9(6): 675-82. [CrossRef]

36. Jawad ZAR, Kyriakides C, Pai M, Wadsworth C, Westaby D, Vlavianos $P$, et al. Surgery remains the best option for the management of pain in patients with chronic pancreatitis: A systematic review and metaanalysis. Asian J Surg 2017; 40(3): 179-85. [CrossRef] 
ORIJINAL ÇALIŞMA-ÖZET

Turk J Surg 2020; 36 (4): 359-367

\section{Kronik panktreatitte ağrı yönetiminin sonuçları: Hindistan'da üçüncü basamak bir hastane deneyimi}

Kavin Sugumar ${ }^{1}$, Aparna Deshpande ${ }^{1}$

${ }^{1}$ Seth GS King Edward Memorial Hastanesi, Cerrahi Kliniği, Mumbai, Hindistan

\section{ÖZET}

Giriş ve Amaç: Kronik pankreatit (KP), geri dönüşü olmayan ekzokrin ve endokrin parenkim tahribatına yol açan progresif bir enflamatuvar hastalıktır. Hindistan bölgesinde KP sonuçları çok az bilinmektedir. Bu çalışmanın amacı, Hindistan'da üçüncü basamak bir hastanede ağrı ciddiyeti açısından KP tedavisinin sonuçlarını araştırmaktı.

Gereç ve Yöntem: Bu çalışma, KP tanısı almış 75 hastayı içeren prospektif kohort çalışmadır. Hastaların demografik özellikleri, semptomları ve görüntüleme bulguları kaydedildi. Ağrı ciddiyeti, vizüel analog skala (VAS) kullanılarak objektif bir şekilde kaydedildi. Cambridge skoru hesaplandı ve hastalar hafif, orta ve şiddetli kategorilerine ayrıldı. Hastalar buna uygun olarak tedavi edildi ve ağrı skorları başvuru sonrası 3 . ve 6 . aylarda tekrar değerlendirildi.

Bulgular: En yaygın etiyoloji alkoldü (54\%) ve bunu idiyopatik/bilinmeyen sebepler takip etti (\%34). Cambridge skoru ve görüntülemede morfoloji ağrı, şiddetine etki etmedi $(p>0,05)$. Sigara içme ve daha büyük kanal çapı, tedavinin ağrıyı azaltma etkinliğini düşürürken daha yüksek postprandial şeker etkinliğin derecesini arttırdı $(p<0,05)$. Analjezikler, endoskopik veya cerrahi tedavi gruplarında ağrı giderme açısından bir fark saptanmadı $(p>0,05)$.

Sonuç: Hindistan nüfusunda KP daha erken görülmekle birlikte Batı ülkelerine kıyasla idiyopatik olguların oranı daha yüksektir. Pankreatik morfoloji ya da sadece Cambridge skorundan ziyade kişiselleştirilmiş bir tedavi planı oluşturma açısndan morfoloji, ağrı şiddeti ve işlevsel durum kombinasyonu kullanılabilir. Mevcut tedavi stratejileri KP tedavisinde etkilidir.

Anahtar Kelimeler: Kronik pankreatit, ağrı, Cambridge skoru, tedavi

Doi: $10.47717 /$ turkjsurg.2020.4924 